\title{
Using historical political ecology to understand the present: water, reeds, and biodiversity in the Camargue Biosphere Reserve, southern France
}

\author{
Raphael Mathevet $^{1}, \underline{\text { Nancy Lee Peluso }}^{2}$, Alexandre Conespel $^{1}$ and Paul Robbins $^{3}$
}

\begin{abstract}
Exploring both ecological and political-economic histories sheds light on the long-term effects of social and environmental changes. Wetlands provide an excellent context for examining the re-working of society-nature relations in a landscape over a long duration. Wetland conditions and social-ecological dynamics show changes rapidly and visibly because they are frequently re-engineered to account for changes in both technology and social preferences. Wetlands are subject to multiple, concurrent property and access regimes that have consequences for both management and ecosystem health. We discuss the social-natural history of the Scamandre Marshes in the western part of the Camargue Biosphere Reserve using a historical political ecology approach to analyze the shifting dynamics between power relations under a variety of political-economic arrangements, and the ecology of the marsh environment. The approach highlights how historical political ecology is a means of identifying historical socio-natures and how European or national conservation actors' constructions of a place as "natural" affect its use, conservation, and management. We show that contemporary ecological dynamics are best explained by past conflicts related to property claims, access to natural resources, and their effects on the flows and composition of water in the marsh. A general model of wetland transformation stresses repeated cycles of stability and upheaval, emphasizing that the lack of historical analysis threatens both wetlands and conflict resolution. No landscape is produced locally or ahistorically. We emphasize here that history is not only a hallmark of political ecology, but a way of understanding ecological changes that can help advance biodiversity conservation science and policy.
\end{abstract}

Key Words: adaptive cycle; biodiversity conservation; Camargue; historical political ecology; wetland management

\section{INTRODUCTION}

Conservation biologists, land management advisors, and policy makers often view environmental problems ahistorically, prioritizing immediate, recent, or proximate political and or ecological drivers. The origins of problems, however, often lie in deep-rooted, invisible, systemic conditions and historical conflicts, claims, and changes in uses and controls over the environment or its component resources. Historical analysis has been an important component of political ecology since it emerged as a field of study in the 1980s (Watts 1983, Blaikie 1985, Blaikie and Brookfield 1987, Hecht and Cockburn 1989, Peluso 1992, Bryant 1997, Neumann 1998, Robbins 2012). Many political ecologists have remained committed to the study of past and present as well as the past-in-present, whereas others have opted to deploy shorter temporal or cross-sectional horizons in analyzing the causes and outcomes of environmental conflicts. While political ecology can thus be argued to have always had a historical component, some scholars have emphasized its historical dimensions and have felt a need to promote an explicit sub-field of historical political ecology (Carney 2001, Offen 2004, Biehler 2009, Carney and Rosomoff 2009, Davis 2009, Peluso 2009, 2012, Widgren 2010, Hecht 2013).

Taking the historical dimensions of social, environmental, and ecological forces seriously is especially important when examining environmental problems in highly modified or engineered environments. In such sites, the explicit roles of humans are clear and acknowledged, as are often conflicting claims. Critical geographers and other scholars have repeatedly shown that some of the most apparently natural systems have been influenced by human inventions, e.g., the Amazon River (Raffles 2001), and are better characterized as "social natures" (Braun and Castree 1998), nature-society hybrids (Zimmerer and Bassett 2003), or the moniker we adopt here, socio-natures (Swyngedouw 1999). Thus, it is a strange anomaly that in some cases where large-scale environmental interventions of the past are recognized, the past is often not studied systematically for contemporary conservation or other management purposes.

The management of the Camargue wetlands of southern France brings into focus many of these issues (Picon 1988, Mathevet 2004). The Camargue constitutes a sprawling wetland in southern France, lying between the Mediterranean Sea and the Rhône River delta. It is a complex hydraulic and ecological landscape whose water and land has been diverted, flooded, dredged, canaled, and cultivated over many centuries for a variety of purposes (Mathevet 2004). In 1986, it was designated as a Ramsar "Wetland of International Importance", an internationally regulated space. This effort is dedicated toward environmental and species preservation, of birds in particular, and the reed bed landscapes that are an important part of the wetland landscape. Its international conservation and its recognition by France comes at a time of a broader "ecologization" of public policy in France and the European Union, which is itself controversial. By ecologization, we mean that emphasis is placed on environmental objectives and processes for planning, zoning, and other land management practices. The ecological re-zoning of rural areas to protect threatened species imposes new norms and challenges the long-held recognition of village and other resource users' management. Ecologization, however, and the concomitant reregulation of these wetlands, has resulted in a notably fierce and visible contestation among a range of regional interests.

${ }^{1}$ UMR 5175 CEFE CNRS, Montpellier, ${ }^{2}$ Department of Environmental Science, Policy, and Management, University of California, Berkeley,

${ }^{3}$ Nelson Institute for Environmental Studies, University of Wisconsin-Madison 
Here, we seek to understand why an eruption of conflict has occurred in this region. Analyzing the historical development of the wetland, both physically and political-economically, we conclude that this current effort is disrupted because it is one layered on top of already existing and unresolved contradictions inherited from the past. The new meanings and allowable practices introduced under contemporary conservation regimes overlay an uneven pre-existing landscape of conflict. Understanding the social-environmental histories of resource and land management in the Camargue reveals the origins of alternative claims and contemporary contestations over these new conservation goals.

We explore the roots of contemporary conservation conflicts in the Scamandre Marshes of the western Camargue. The recent decline in both the area and quality of the reed beds, as well as significant landscape changes in the freshwater area of the western Camargue, have been perceived and represented by conservationists and reed harvesters as an environmental problem of great importance, both to France and throughout the Mediterranean (Barbraud and Mathevet 2000). We examine the details of struggles to control the uses, meanings, water, and value flows within and from the mixed land-and-water-scape of the marsh. Specifically, we are interested in the contexts and contests that preceded the ongoing conflicts since the mid-1990s between hunters, reed harvesters, fishers, landowners, and conservationists. Our intention is to examine selected moments of the Camargue's social-ecological history having to do with the reed beds: their ecology, uses, property and access rights, harvest practices, demands, and fit within the political-ecological relations of the Scamandre Marshes and the broader region.

We begin by considering the role of history in the field of political ecology. This is followed by a description of the complex ecology of the contemporary Camargue and its current situation. We then explore the history of the marshland over several centuries to reveal the repetition of certain patterns of conflict and reregulation in different eras, with particular attention to the ways that previous resolutions of conflicts create systems of accumulation as well as new sources of conflict for later management. We then propose a general model of periodic stability, capital accumulation, crisis, and re-regulation of the marsh in an effort to point to a more universal set of concepts for the field. We close with the theoretical and practical lessons that this analysis provides.

This case study demonstrates how the power relations and extant ecology of one moment influence or produce those of subsequent moments. For some 300 years, the re-engineering and rechanneling of water and its access institutions have affected the marsh's dependent resources (reeds, birds, fish) while producing the environment called The Camargue. We show that today's conservation policies initially took insufficient account of the region's social-ecology or social histories, even though these moments were extremely important in creating the flows of water and the presence of various resources in the present. The lack of historical analysis threatens both wetlands and conflict resolution. We emphasize here how historical political ecology is a means of identifying historical socio-natures and a way of understanding ecological changes that can help advance biodiversity conservation science and policy.

\section{HISTORICAL POLITICAL ECOLOGY}

We understand and argue for political ecology as an intrinsically historical approach because contemporary political-ecological configurations need to be understood as constructed in and through past processes, transformations, and dynamics. Political ecology has also claimed historical analysis as a fundamental component, yet not all political ecologists use history as part of their analyses (e.g., Bryant 1997, Robbins 2012). However, resource, environmental, territorial, or other land-based relations are always better understood and explained as moments in temporal trajectories (e.g., LeFebvre 1991, Offen 2004, Kosek 2005, Davis 2007, Peluso 2012).

Landscapes and their components are not permanent or static entities, but situated, produced, and representational spaces. Conflicting claims may be understood as rational from the situated perspectives and situated historical trajectories of the claimants. Claims do not emerge out of nowhere; they are products of complex webs of social relations and accumulated notions of rightful access or patterns of control (Peet and Watts 1996, Neumann 2005, Robbins 2012). Thus, historical political ecology (HPE) is political ecology with an emphasis on history in which the historical dimension is not included foremost to explain the present, but also as a means of informing present-day politics for improving social justice and nature conservation (Offen 2004).

We thus see contemporary environmental problems as products of complex past conflicts and their resolutions. We stress not only situated knowledges (Haraway 1988), but situated practices as well, looking to how socio-natural histories have been constituted (Hecht and Cockburn 1989, Crumley 1994, Carney 2001, Peluso 2012). The case of reeds in the Camargue demonstrates that relational socio-natural histories are crucial to understanding social-ecological dynamics in the present and contributes a critical perspective to ways of knowing and interpreting these dynamics.

We have also been inspired in this piece by the insights of French geographers and the French Annales School. The Annales school has already made great use of historical analysis in a way that mirrors what we mean with HPE, although its emphasis on deep history and the effort to identity long-term cycles and patterns generally goes much further back in time than does HPE in general. Ferdinand Braudel, E. Le Roy Ladurie, and other great historians in this school combined scientific and social science questions about the complex relations between the concerns of the two fields in studying the longue durée (long term) of processes and places, rather than focusing on short-term or immediate contemporary events. Their approach inspired the American world systems theorist Immanuel Wallerstein and other early global sociologists, who attended to society's (and sometimes socio-natures') uneven and unpredictable trajectories, rather than simply to events along the path (Braudel 1985, Moore 2010). World systems theorists and French Annales historians seek to explain the long, slow contributions of cyclical and conjunctural histories to processes of landscape creation (Wallerstein 1974). These are the multiple social-environmental interactions that occur in a specific place, where various components exhibit different space-time levels of organization yet also co-evolve over time and generate a complex historical trajectory of the socialecological system (Berkes and Folke 1998). By mixing multiple temporalities (Crumley and Marquardt 1987), including the 
Fig. 1. Location of the Scamandre Marshes (red circle). Main land uses of the Camargue Biosphere Reserve, 2013. The new reserve created recently on abandoned salt pans is indicated by the red dotted line; other land uses such as other crops farming are in grey.

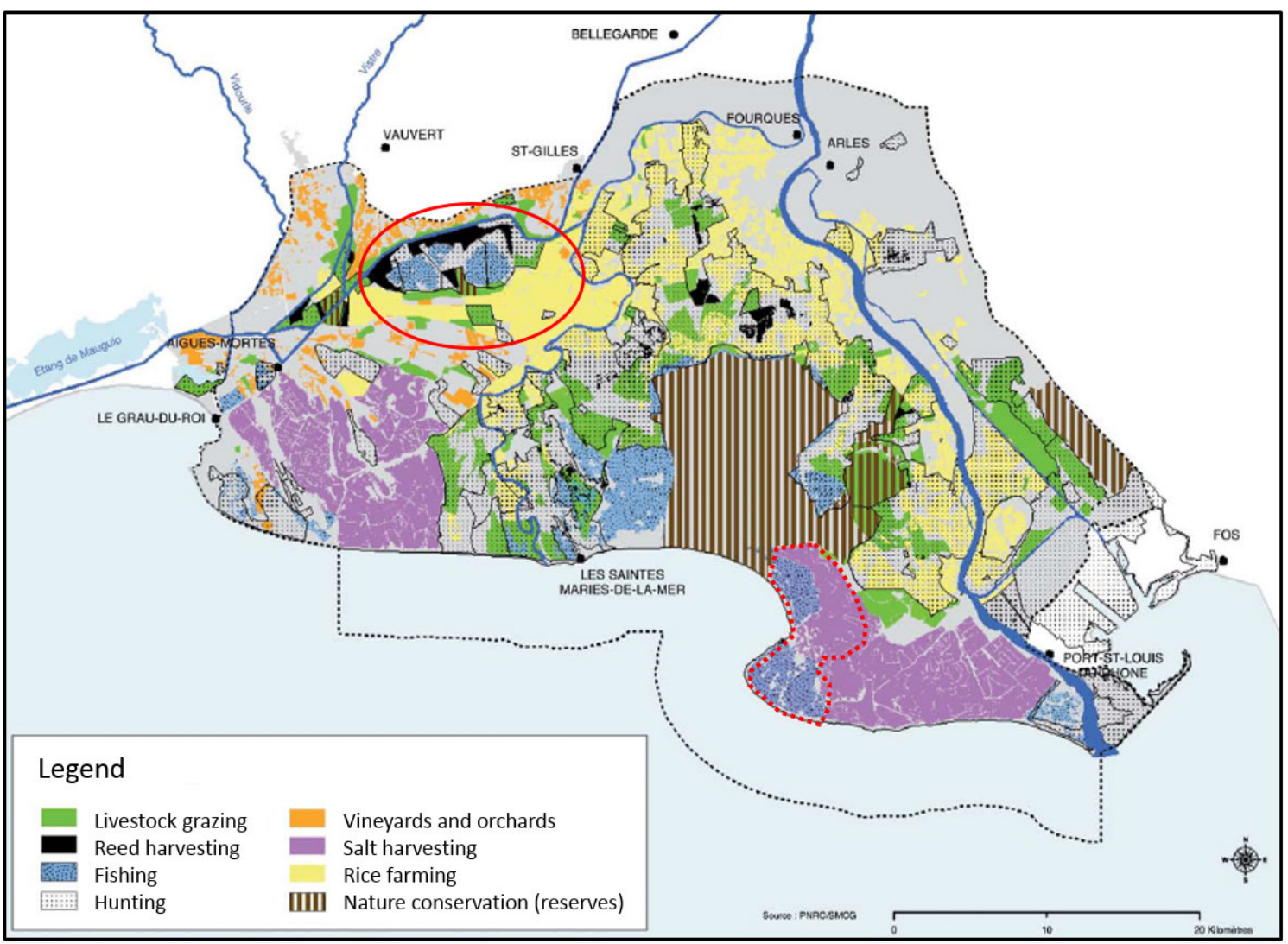

natural cycles through which species' and habitats' biological rhythms change, the intensity of exploitation of natural resources (Gunderson and Holling 2002), and the life-cycles of components, the complex social-ecological dynamics creates an adaptive cycle that alternates between periods of accumulation and transformation of resources and periods that make opportunities for change and innovation (Holling et al. 2002).

Thus, we depend here on a variety of data sources, both immediate and long-term, including contemporary field evidence from ecological monitoring, social surveys, observations and informal interviews, historical evidence collected from archives, and visual representations such as photos, drawings, and maps of the Camargue region from earlier and contemporary times. The case demonstrates moments of intense contradiction at points of political economic change, resulting in crises or major conflicts leading to changes in water regimes, property rights and access, and in the landscape composition of the marsh. To emphasize our point: the ecologies of the marsh at any point are dependent on the cumulative effects of various interactions between human decisions and actions in and around the resources of the marsh. Both Foucault (2004) and Deleuze (1988) showed that the history of the present means understanding history as a network of institutions, discourses, and practices understood as both powerladen and more or less effective. Because the task is to determine what social-ecological changes resulted from past configurations and why (Fairhead and Leach 1995, Hoben 1995, Mathevet and Poulin 2006), it is not possible to marginalize or disregard the history.

\section{THE WESTERN CAMARGUE WETLANDS}

Today's Camargue is a site of global conservation concern. The region comprises approximately 145,000 ha, extending across the Rhône River delta, on France's Mediterranean coast (Mathevet 2004; Fig. 1). It has been a World Biosphere Reserve in UNESCO's "Man and the Biosphere" (MAB) program since 1977 and a Ramsar Convention site since 1986. France designated its central and eastern areas a Regional Natural Park (Parc natural regional), which are contract-based parks established between local authorities and the French national government that must promote natural and cultural heritage conservation. Covering approximately 60,000 ha, different types of freshwater marshes within the Park are covered in reeds, brackish swamps, ponds, and lagoons. In addition, it supports halophytic scrublands and steppe communities dominated by glasswort. The rest of the area is under intensive rice and wheat agriculture. Unlike many conservation areas designated by MAB/UNESCO, most of the Camargue's land is privately owned, although $>20 \%$ of the delta has been acquired by national or regional government conservation entities in the form of national and regional nature reserves, local publically administered swamplands, and Coastal Conservatory sites. 
The Camargue marsh's reed beds are dominated by common reed (Phragmites australis). Reed beds have been recognized as important habitats for faunal biodiversity conservation in Europe (Poulin et al. 2006). The Camargue encompasses approximately 8000 ha of reed beds, the second largest reed production area in France after the Briere Regional Natural Park, and in Europe, after the Danube Delta. The largest reed bed in the Rhône delta lies in the Scamandre Marshes of the northwestern Camargue, occupying nearly two-thirds of the 3500-ha marsh. These reed beds have been used since antiquity for seasonal activities such as waterfowl hunting, reed harvesting for fodder or thatch, grazing, and fishing. Records dating back two millenia to Roman times exist for the Camargue, and medieval church settlements and monastaries provide a glimpse of how monks, parish members, and strangers lived in and used these landscapes in earlier times. From antiquity, people have drained the marshes or controlled water flow by building dikes, small dams, irrigation networks, and drainage systems, or by installing rudimentary pumps. Only more recently has the marsh become attractive for preservationist uses such as ecotourism and nature conservation (Mathevet 2004).

Reed beds perform many ecological functions. They contribute to the retention of sediments that circulate in canals and rivers, protect banks from erosion, and improve water quality through purification services. Reed beds also provide food, refuge, and shelter for many animal and fish species. The Camargue's reed beds provide nesting areas for birds today designated as rare and/ or vulnerable in Europe (Barbraud et al. 2002) such as the bearded tit (Panurus biarmicus), the purple heron (Ardea purpurea), and the Eurasian bittern (Botaurus stellaris). Bitterns are a heron of great importance to the EU Birds Directive (Poulin et al. 2006).

The main factors governing reed bed dynamics are seasonal water levels and salinity (Mauchamp and Mésleard 2001, Mauchamp et al. 2001). Reeds can tolerate high concentrations of salt $(<15$ $\mathrm{g} / \mathrm{L}$ ), as well as flooding and intensive harvesting. However, a combination of simultaneous stresses or changes can accelerate the decline of reed abundance and quality (Mathevet et al. 2003). Both of these key ecological processes (water level and salinity) have been subject to human modification, for example, by the construction of dikes to protect agriculture and residences from flooding of the Rhône or the Mediterranean. Reed beds have remained largely in place, even though they disappear for periods when water engulfs them. They can also be transformed into less productive halophytic scrublands or become forests through the growth of dry matter. Their actual transformations and the lengths of time they remain in these states depend on the water flow regime, water availability, and the level of salinity (Hawke and José 1996), and thus also on management strategies, because of their location and high frequency of use.

Like other parts of the Camargue, the Scamandre Marshes comprise a mixture of public and private land (Mathevet et al. 2003). In the mid-1990s, environmentalists and reserve managers began to question the prudence of allowing multiple uses of the reed beds. The demand for roof thatching materials was increasing in northern European countries, leading to intensified mechanical harvesting with large machines that cut and collected reeds (Honegger et al. 1992, Mathevet and Sandoz 1999). At the same time, the number of nesting pairs of purple herons appeared to be decreasing. This was significant because the site was regarded as the Mediterranean bastion of the species (Barbraud et al. 2002). Research in the 1990s indicated that the regulations governing the administration of communal land use rights, passed down from barons and abbots since the 13th century (Teulade 1999), were being changed and expanded, allowing a shift from a declining manual reed harvest (reserved to residents) to mechanical harvest by few residents and a growing number of operators coming from neighboring communities (Mathevet 2004). At the same time, communal reed beds were still being used by residents and other rights-holders for hunting, grazing, and fishing (Barbraud and Mathevet 2000).

With new demands on the reeds and waters, a decline in longeffective management practices, and increases in private, national, and international claims, conflicts were rampant. Users of public and private lands were in constant, often violent, competition for access to land and water (Mathevet 2004). Some users deliberately attempted to destroy irrigation or drainage networks, individuals got into fights over access, and arsonists burned harvested reeds waiting for processing and shipment. Local authorities and environmentalists organized public meetings in 1993-1994, when they agreed that the management problems derived in part from a lack of coordination among users and gross misunderstandings of both recent and long- established patterns of seasonal water level management and fresh or saline water distribution (Barbraud and Mathevet 2000).

In the 1990s, a new generation of conservation scientists, working for the local authorities, promoted management practices that would better maintain the reed beds, preserve wildlife, and facilitate long-standing human activities in the marshes. Over the subsequent decade, studies were conducted on regional socialecological interactions and on practices and rules in the various commons and properties constituting the wetland, including collective management of water levels (Mathevet et al. 2003, Poulin et al. 2006). The use of hydrological models, agent-based models, and role-playing games allowed local stakeholders to explore potential water management scenarios and to become aware of the social and ecological trade-offs (Mathevet and Poulin 2006, Poulin et al. 2009).

Researchers worked closely with local actors, developing both descriptive and analytical approaches to experimental management as part of the implementation of European agroenvironmental policy such as the requirement to implement new contractual approaches (Mathevet and Sandoz 1999), especially for reed harvesting, and a European Union-funded project to prevent decreases in the French bittern population in this habitat. This action-research led to changes in some practices such as methods of reed harvesting, which were required for the implementation in France of the first EU Natura 2000 contract, the key tool of the EU biodiversity conservation policy. Despite these successes, the time lag between collective efforts and expected benefits on the ground (2001-2010), and the unabated political conflicts between local water-management authorities and supra-local authorities in charge of regional and environmental planning, led to a reduction in policy initiatives and scientific studies (Couespel, unpublished reports; Mathevet, unpublished reports).

The management plan collectively developed and approved in 2001 by various governing bodies and user groups (the prefecture, 
the local commune, the syndicate, and user representatives) was never implemented, even though scientists, managers, and various resource users had come to understand the Camargue's diverse water management needs, practices, and ecological consequences. Conservation scientists also changed their early representations of the region as containing the last pristine reed beds to a more nuanced understanding of a human-constructed landscape.

At the end of the participatory process, some long-standing political conflicts (mostly those concerning property and use rights) remained unresolved and potential solutions unimplemented. This was partially because of inadequate involvement of hunters and upstream rice farmers, both of which had specific needs for brackish or fresh water. Evidence from the field indicated some improvements in collective management of seasonal water levels, greater surface area stabilization, and better reed bed quality in some parts of the marsh. The improvement of the reed beds was also aided by the major floods of 2003 and the implementation of summer drying periods suggested by new leadership in the communal hunting association. Conflicts between stakeholders seemed to decrease during the most recent years (2007-2014; Mathevet, unpublished data). However, during that time, environmentalists and the supra-local authority (i.e., the Syndicate) dramatically reduced their interactions with land users and focused on managing a new nature reserve created from the purchase of two estates in the 1990s. Efforts to negotiate a stronger agreement between marsh resource users, the managerial syndicate, and the bird preservation site managers began in 2013, benefiting from data collected in the two previous decades.

\section{HISTORICAL POLITICAL ECOLOGY OF THE SCAMANDRE MARSHES}

Current struggles over the Scamandre Marshes reflect commonly noted conflicts between locals and state or non-profit conservation authorities, in which distant state authorities assert claims to areas with local use rights (Peluso 1992, Neumann 1998, Brockington 2002). Looking back approximately 400 years, however, shows that some current conflicts derive from repeated patterns of competing ecological and property priorities.

From the 16th century to the present day, four cycles with similar dynamics can be distinguished. The key repeating cycle is the struggle of competing actors to control water levels and the salinity of the marshlands to facilitate specific, private, and often incompatible uses. As a result, water, long considered a public resource, is increasingly being mustered for private use and facilitating the privatization of other resources in the reed beds. New private and public claims are being put forward, including a lawsuit. At the same time, local inhabitants have no intention of forfeiting their communal properties, rights, or traditional practices and rights, which they have enjoyed since the Middle Ages (Guigou 1978, Teulade 1999, Mathevet 2004). Reconstructing the region's histories of social-environmental change and showing how changes in property rights have affected the marsh ecology provides some clues to the origins of the current problems arising in recent attempts to manage the marshes.

Cycle 1. From healthy reedbeds to Salicornia scrublands, 17th and 18th centuries

From 1599, the King wished to drain the French Kingdom's marshes (Fig. 2A) to improve them for farmland; the regional states and power-elites of Languedoc did not respond positively to this idea (Comte de Dienne 1891). Before the 17th century, the marshland region, then known as eastern Languedoc, was home to Cisterician monasteries, the Order of the Cross of Malta, and several baronies. Each of these were adjacent to or composed of associated settlements of peasants, serfs, and fishers, who provided their feudal-era overeseers with their labor and products of the land and marsh (fish, game, and fodder) in exchange for access to land, fishing, and reed harvesting rights. ${ }^{[1]}$ They had always been involved with the marshes' management (Cabot 1991, 1994). It took more than a century to realize the King's aspiration.

Extreme weather conditions battered France throughout the 17th century, and by the century's end, the country had experienced several devastating famines. Religious violence also plagued the south. Capitalist relations, begun approximately one century earlier, had started to impinge on local land use and improvement within France as elsewhere. Hoping to discipline this southern region of the country, Colbert, the Chief Minister to Louis XIV, suggested the development of an inland waterway or canal (Comte de Dienne 1891). The canal would facilitate the transport of wheat and arms between the Atlantic coast, the Mediterranean Sea, the region of Provence, and the Rhône valley. French historians have described the conflicts related to the construction of the main canal and its effects on the wetland's ecological dynamics during the 17 th and 18 th centuries (Guigou 1978, Vidal 1980, Teulade 1992).

At first, the King gave the rights to a private contractor, Jacques Brun, to dry the wetland and cultivate the newly created arable lands. In 1645, he finished plans for such a canal to transport goods between the Mediterranean and the Rhône. Claiming concerns about the canal's potential effects on local people, the State of Languedoc refused, choosing instead to preserve its healthy regional economy based on fishing, hunting, fodder production, and livestock grazing. In other local resistance, resident communities refused to help repair the Rhône River's dikes after floods. In their view, the floods of the Rhône provided benefits (fish, fresh water) and facilitated the growth of reeds and other grasses for grazing.

In 1701, the King authorized the Marshall de Noaille to drain the marsh and create the waterway canal; to achieve this, he made the Marshall provincial governor of Languedoc (Comte de Dienne 1891). Prior to this, in 1681, the Canal du Midi had been completed. Although it did not reach the Rhône, it incorporated much of the southern region into France and served as a shortcut between the Atlantic and the Mediterranean, avoiding the long sea voyage around Spain and the subsequent long trip by dirt roads. Given the changing political economies of the times, local elites were pleased that the Canal du Midi improved shipping from Languedoc to the rest of the Kingdom, allowing them to profit from the infrastructure. Just after it opened, however, the insurrection of French protestants (Huguenots) in the neighboring Cevennes region caught up the south in political violence until 1715. This prevented the implementation of further drainage or cultivation projects in the lowlands.

Twenty years later, M. Barillon was put in charge of creating another canal to connect the Canal du Midi to the Rhône. Again, eight years of fighting between the center and against severe local opposition ensued (1738-1746). Local communities opposed the 
Fig. 2. Simplified maps of major land-cover changes in Scamandre Marshes, 1600-2014, in the Camargue Biosphere Reserve, France.

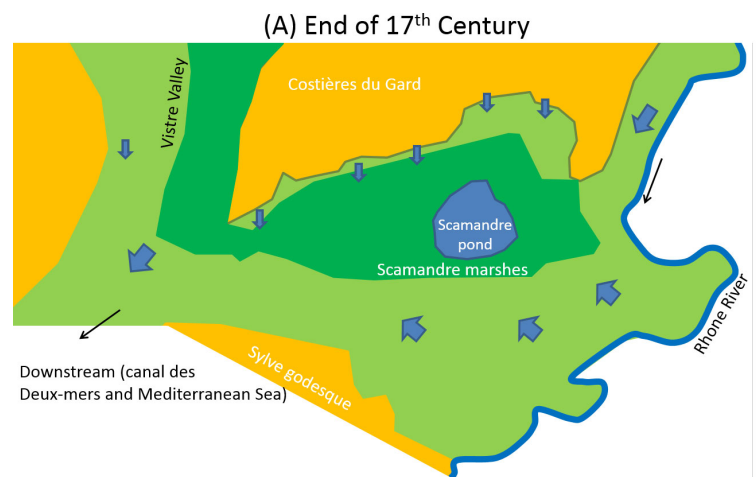

(C) $1823-1945$
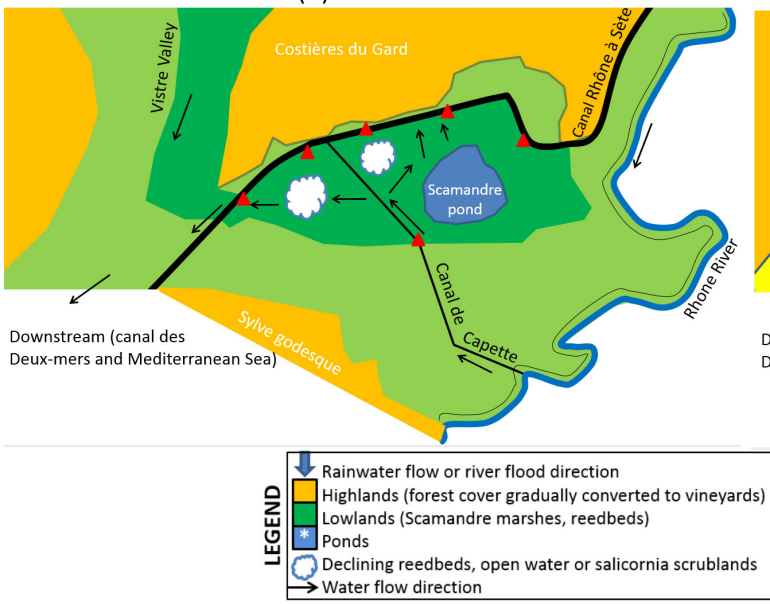

(B) $1700-1823$

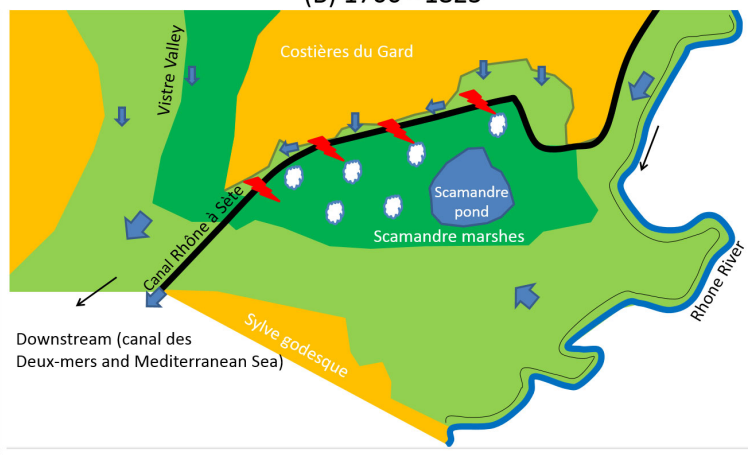

(D) 1945 - Present

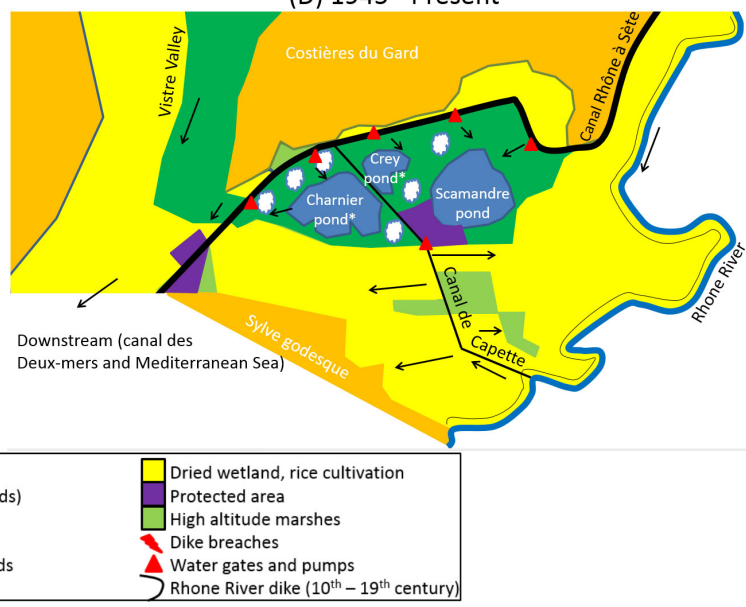

project for the same reasons they had earlier, i.e., for fear of losing access to their resources, and this time, provincial authorities joined them, though for different reasons (Boutonnet 1963). Many local elites had invested in salt production along the Mediterranean shore. Some preferred constructing a road rather than a canal to transport salt (Teulade 1992). Others, boat owners and captains, preferred to develop the harbor to facilitate cabotage (the coasting trade). Conflicts also arose between the cities of Nimes, Montpellier, and Lunel, all of which were afraid that a new canal would empower Beaucaire, another regional center, at their expense (Vidal 1980).

In 1746, the King acquiesced to several of the regional elites' demands. He granted the Languedoc state the rights to build the canal (Comte de Dienne 1891). He appeased some of their powerful constituents by promising to build a network of commercial roads between Burgundy and Aquitaine. The project to drain the wetlands was also separated from the digging of the new waterway. However, land owners and other marsh resource users remained fiercely opposed (Guigou 1978). Further negotiations and land-use changes eventually led to tradesmen, landholders, and merchants becoming interested in the canal's development as they developed vineyards and produced wine in the surrounding hills north of the wetland. Indeed, they produced a new demand for the canal; it enabled them to transport their wine cheaply to expanding markets around France (Cabot 1994). In 1773, local canal opponents agreed to allow canal construction if they could retain their prior use rights. The King also allowed the States to borrow funds to dig the canal. Construction began in 1777 , and the canal was opened to transport ships between Aigues-Mortes and St Gilles in 1789. The remainder was built over the subsequent two decades, spanning the revolutionary period (Lentheric 1880).

The construction of this canal and the land-use changes in the vicinity had several consequences for the ecology of the marshes and for resource access. First, the canal cut off the previous pathway of freshwater into the marsh. It reduced freshwater inflows by diverting runoff from the northern hills and tributaries of the Rhône directly into the sea, rather than to the marsh (Fig. 2B). The marsh's loss of a regular influx of freshwater caused a general degradation of the wetlands and the local flora and fauna, including a loss of reed bed area (Vauvert Municipal Archive C75, 4). The wetland dried up on the south bank of the canal, having lost the rain water from its former catchment area. As reeds and fresh water disappeared, the livelihoods of fishers, fodder producers, and livestock breeders were affected, as they had feared. Only the Scamandre pond remained, thanks to a small irrigation canal that brought water from the northeast.

Cycle 2. After the revolution: from Salicornia scrublands to reeds, late 18th to mid-20th centuries

In response to the loss of fresh water, local actors breached the dikes of the waterway canal. This vandalism led to a new water 
management regime favorable to fishery production. ${ }^{[2]}$ The outcome hurt the interests of reed harvesters because the canal downstream brought tidal waters into the marsh from the sea and increased the salinization of the entire marsh during reflow periods. Thus, salt water reached the wetland in certain seasons, relative salinity rose, and this led to increased degradation of the reed bed. The newly created wetland environment could no longer support traditional resources. ${ }^{[3]}$ The resulting economic crisis continued throughout the French Revolution.

This was a difficult period for all users of the marsh, including newly bourgeois landowners who claimed two-thirds of the old common marshes in the new private property systems arising in the revolution's wake (Guigou 1978). When the private company charged by the national government with operating the waterway canal began its work (Bouvier 1825), it plugged the breaches. This facilitated boat movements but again changed the hydrology of the marshes, causing another destabilization of the wetland and creating new management problems. For example, the newly formed municipal government had to address the economic difficulties and social conflicts created by the re-salinization and degradation of wetland resources; the local economy had collapsed.$^{[4]}$ Moreover, the drying marshlands and small pools of stagnant water were prime breeding grounds for malarial mosquitos, increasing illness and death rates (Vauvert Municipal Archives, CM, 6 May 1821).

During the Restoration period (under the constitutional monarchy from 1814-1830), the national government ordered engineering works for irrigation of the wetland. In 1823, a treaty governing use of the marshes was negotiated by the commune authority, the private company in charge of the waterway canal, and one of the land owners in the marsh. The Treaty of Marshes established patterns of seasonal water flows and water distribution among the users of the time. It was a democratic, negotiable, legal-institutional instrument that regulated allocation of fresh water to maintain marsh ecology for specific uses. The creation of the new irrigation canal and network during the 1820 s allowed fresh water from the Rhône River to flow directly to the marshlands via the Canal de Capette (Fig. 2C; $3 \mathrm{~S}$ 111, Gard Departmental Archives, Rapport de l'Ingénieur Bouvier le 7 avril 1835). The canal thus restored the wetland and once again established a water regime favorable to reed harvesting, hunting, and fishing (Boutonnet 1963; Gard Departmental Archives).

This social-environmental management regime produced a long period of relative environmental stability of almost 150 years. From the mid-19th century to World War II, many documents attest to the regeneration of natural resources in the are $\mathrm{a}^{[5]}$ in part because of the recognition of local uses and property rights. The municipality was vested with the responsibility for changes in management. Local historians have shown that local people regarded this period as a "golden age" in which most users were accommodated by seasonal management of water levels (Teulade 1999; Mathevet, interviews and unpublished data).

Nevertheless, significant political-economic changes occurred throughout this century and a half, affecting the resource demands of various marshland actors. Until the mid-20th century, new tensions emerged over distributing the costs of infrastructure maintenance, the specifics of freshwater management and flow inside the marsh, and flows between upstream and downstream users. ${ }^{[6]}$ Conflicts often occurred between landowners, resource users, the commune authority, and the private company in charge of the canal. In the late 19th and early 20 th centuries, for example, canals and ditches were poorly maintained and individuals developed their own dams and levees at will, aiming to improve irrigation on their lands. ${ }^{[7]}$ The Treaty of Marshes changed at least five times, and tensions continued between the canal company, the Vauvert commune, and the bourgeois landlords. These events might be seen as less than golden and even less than stable.

Using maps to reconstruct and reinterpret environmental use and change in this period, we realized that earlier historical accounts had missed the appearance of two large ponds (i.e., covering approximately 700 ha), Charnier and Crey ponds, sometime during the late 19 th or early 20 th century (Fig. 3A, B). As late as 1825 , these did not appear on maps prepared by the civil engineer Bouvier to plan for the hydraulic works. His maps were renowned for their accuracy, implying that such ponds in fact did not yet exist. None of the earlier archival maps from monasterial records, feudal estate holdings, or in regional or national government archives show the two ponds. However, the Charnier Pond is first verbally mentioned in the Vauvert Municipal Archives just before World War I. ${ }^{[8]}$ Both ponds also appeared on a 1944 map made by the U.S. Army based on aerial surveys (Fig. 3C). We did not find any evidence of digging projects or comments related to human-made pond creation in the archives, and interviews with local historians indicated that the appearance of the two ponds was not identified or discussed before our study. We thus concluded that the two, now large, ponds did not exist prior to the waterworks projects of the early 19 th century. Rather, the Charnier and the Crey ponds formed in response to repeated floods after years of drainage, poor management, and increased marsh salinization. ${ }^{[9]}$ As the reed beds shrank, these two new ponds progressively formed next to Scamandre.

\section{Cycle 3. From reeds to rice, 1945-1970}

After World War II, the Marshall Plan led to the mechanization of local agriculture. Demand for fodder declined as tractors replaced beasts of burden on farms in the Camargue and the rest of France (Mathevet 2004). The Plan provided funds to improve drainage and irrigation. Reed harvesting practices also changed, which altered the seasonality of reed production and water demands. Previously, green reeds had been harvested during the summer, the seasonally dry period of Mediterranean wetlands. After the war, dry reeds were in demand for thatched cottage roofs in western and northern France and in northern Europe. Camargue farmers began to cut reeds in winter using new, specialized machines that required low water levels in winter and early spring. The mechanically harvested area increased dramatically during recent decades, especially on public lands, even though misuse of the harvesters could compact the soil and obstruct reed growth.

Rice farming developed rapidly in the delta, particularly in the 1950s and early 1960s. With the return of French Pieds Noirs (French citizens who had lived in Algeria before its independence) from Algeria, the national government gave them land and support for planting rice, and rice paddies replaced many vineyards. This new land use led to yet more drainage systems, a new shift in the demand for fresh water, and different cultivation practices in the former marshlands. 
Fig. 3. Four maps of the Scamandre Marshes showing major changes in the landscape, especially the formation of two new large ponds, western part of the Camargue Biosphere Reserve, southern France. (A) Details of 1698 map made by H. Gauthier, Diocèse de Nismes. The small pond below the Scamandre Pond is Escoute Pond, later drained. (B) Details of 1850 map made by E. Dumas, Carte Géologique du Departement du Gard. The tiny remains of Escoute Pond are visible to the south of Scamandre Pond. (C) Details of 1944 map made by the U.S. Army, sheet XXVIII-43/44, southern France, 1/25,000, based on aerial photographs from 1942. (D) Details of map made by Institut Géographique National, 2011, The state of the wetland, 1/25,000.

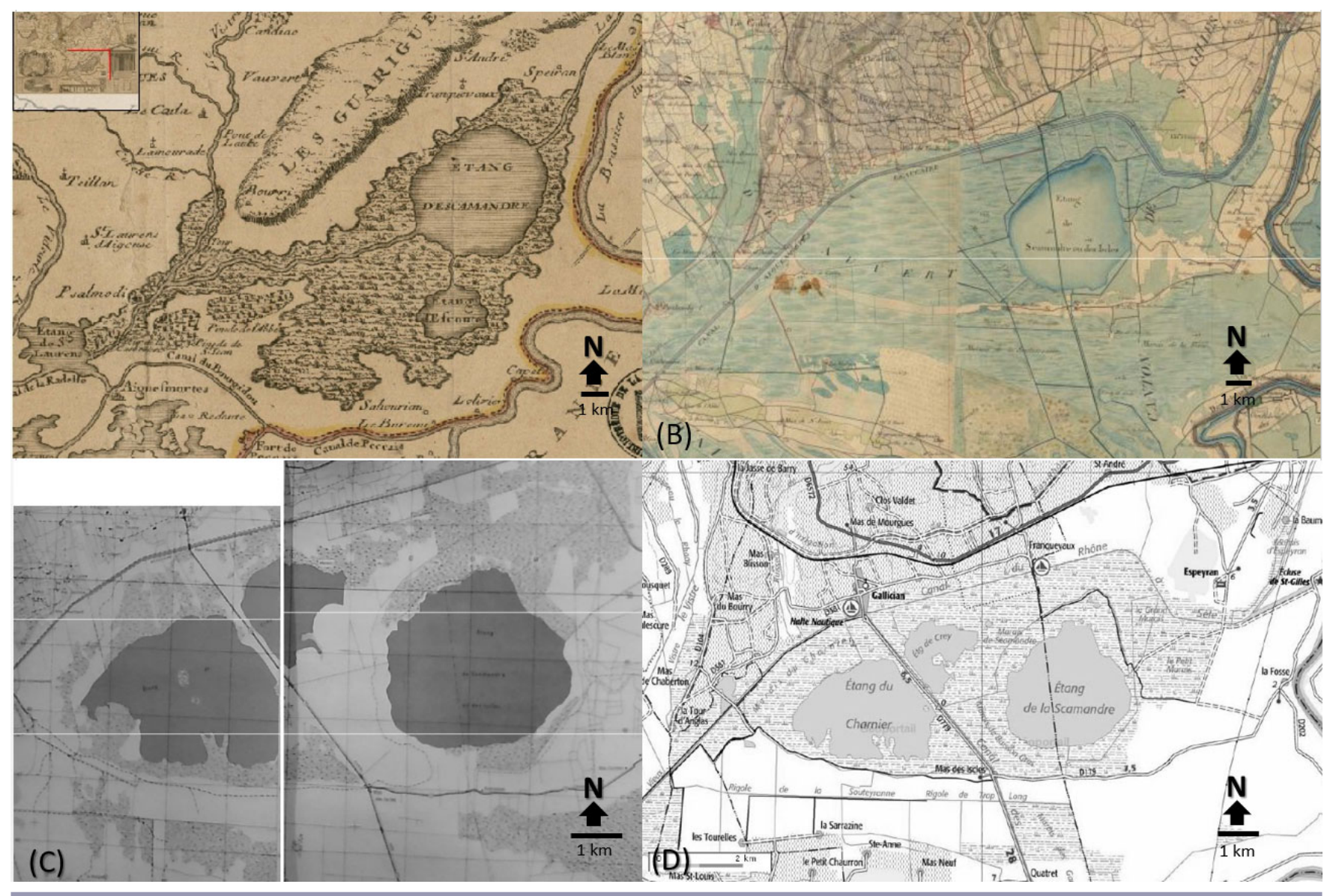

The wetland's water regime was again disrupted by the drainage of lands upstream from the Scamandre Marshes (Fig. 2D). National politics thus drove two major sets of socialenvironmental changes: the repatriation of the Pieds Noirs at the end of the Algerian War, and the drive to achieve national food self-sufficiency. The cultivation of food in the dry marshes became a national state priority, thereby affecting land and water management and requiring new institutional responses (Vassas and Vigneron 1980). The national government changed the Treaty of Marshes in 1969, creating a water management regime favorable to upstream rice farming development. The new arrangement was significantly less attractive to downstream users of the Scamandre Marshes because they received less freshwater in spring and summer (Fig. 2D). However, it was politically justified for the sake of national food self sufficiency by national planners who saw rice farming as more crucial than duck hunting (a leisure activity), reed harvesting (an industry that was dying), or livestock grazing (a less profitable industry).

The resulting hydrological regime engendered an environmental problem within the present Scamandre Marshes. As dry land was enclosed for rice farming, private wetland owners became empowered. They built small dikes, irrigation canals, and pumping stations in the waterway canal to maintain high water levels inside the permanent wetlands throughout the year and to avoid water shortages during key parts of the hunting and reed growing seasons. The enclosures facilitated relatively autonomous water management but were damaging to the environment in the long term. Enclosure and private use of water precluded coordinated flushing of the whole marsh to drive down salinity levels. From this new set of environmental conditions, both public and private hunting were favored, which led to the sale of private hunting leases (Mathevet and Mésleard 2002). Hunting conflicted with the reed industry, upsetting the environmental balances and land-use agreements negotiated and managed over the previous 150 years.

\section{Cycle 4. New commodities, enclosures, and the rise of bird} conservation, 1980s-1990s

By the 1970s and 1980s, French hunters increased in number and had formed an important local and national political lobby. The increase came from several changes in the political economy and 
political ecology of the region. The numbers of fishermen and manual reed-cutters had declined further with the changing global economy (Mathevet 2004). Many people moved, and some residents worked outside the Camargue in industry or urban areas. However, the government instituted paid vacations as a national benefit, enabling many industrial and urban workers to return to their rural roots and engage in hunting. Hunters had always hunted waterfowl in this area, but as their numbers increased, they became a more powerful force in the marsh's public areas. Hunters allied with the few remaining fishermen and some manual reedcutters to force the maintainence of high water levels to attract wintering waterfowl, negotiating against the disruption of water levels that better served rice farmers upstream. The quasipermanent closure of the main irrigation gate on the Canal de Capette (Fig. 2D) by the upstream agricultural landowner association in charge of it led other landowners and wetland users to install more pumps and watergates on the waterway canal (Canal du Rhône à Sète) for their private use. However, this water was far from fresh. Depending on the season, it was rendered brackish from seawater flows from the Mediterranean, polluted by industrial uses on the Mediterranean shores, and polluted by waste from cities located upstream on the waterway canal or the Rhône.

During the 1990s, institutionalized nature conservation arrived in the wetland. The main groups were involved in habitat restoration and water control to protect certain reed bed nesting birds. European Union regulations and corresponding French regulations regarding conservation had immediate, significant, and long-term effects on marsh management. The concern with biodiversity conservation was supported by a new actor, the Syndicat Mixte pour la Protection et la Gestion de la Camargue Gardoise (The Joint Syndicate for the Protection and Management of the Gard Department Camargue), funded by the General Council of the Department of the Gard. The Department is one of three levels of government below the national level, i.e., between the Region and the Commune. The Syndicate's goals were to control water management and to limit the area of the reed bed being harvested mechanically because it threatened nesting sites, especially those of the purple heron. The purple heron also requires high water levels for breeding in spring. The intervention of institutional conservation interests, granted authority by the EU's new regulations, led to the creation and expansion of new protected areas. For example, a former agricultural estate was purchased that had combined rice production, grazing, and reed beds. Much of that land was restored to a wetland regime, and the reed bed is managed for harvesting, specifically to show that production activities and bird protection can be achieved simultaneously. New conflicts arose as well concerning which institutions have ultimate authority over water management decisions.

The new overarching public authority, the Syndicate, was intended to engage local, regional, and national institutions and communities in decision-making. Members of this authority worked with conservation scientists to update the Treaty of Marshes. Conservationists envisioned the new treaty as a management plan combining community participation with the deployment of hydraulic engineering works to reconcile the diverse wetland activities that have emerged over the years.
Through EU agro-environmental measures and Natura 2000 contracts, the new public authority has forged an alliance with some reed harvesters and the conservation scientists so that both production and conservation activities can proceed within the broader boundaries of the marshland, leading to some messy conflicts with duck hunters over access. This management plan faces another crisis, however, as conflict over governance has arisen between the municipality charged with managing the public marshland's water and the public authority in charge of planning for the entire region of the western Camargue (i.e., the Syndicate). The latter organization also invests in land and waterworks for cultural landscape conservation and tourism development. Due to this conflict, the official management plan is unlikely ever to be implemented, although some local actors manage collectively held water gates according to principles jointly conceived and carried out.

\section{Camargue's cycles of capital accumulation and social- environmental change}

Reviewing each of these eras of conflict and re-regulation and exploring their spiraling interactions, we suggest a more general model to describe periods of relative stability and crisis in the historical wetland environment of the Camargue (Fig. 4). This model posits ongoing cycles of capital accumulation and socialenvironmental changes occurring in repeated phases over the long historical arc of wetland creation and destruction in the European, and especially the southern French, context. Thus, this wetland becomes a window through which we see the dynamism of the broader political economy, relations between claims and counterclaims, multiple uses, and ongoing, conflicted transformations.

Fig. 4. A general model of cycles of capital accumulation and interventions in the western Camargue, France.

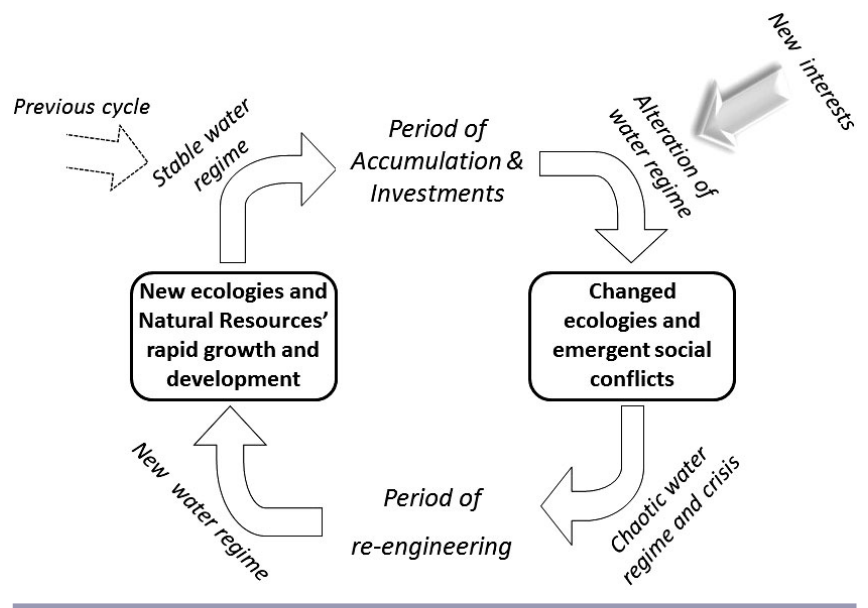

A simplification of these repeated cycles of regime change (Fig. 4) suggests generally how new resources are produced from the waters and lands comprising the Scamandre wetland, as well as how new circumstances lead to new processes of regime change (Bakker and Bridge 2006). The putative starting point really represents only a moment emerging from a previous cycle. That moment represents a configuration of resource use and a regime of access mechanisms within the marsh. Use and access produce a stable environment for capital accumulation, for a period, with 
repeated infrastructural investments (e.g., water gates, canals, or land drainage) designed to produce a specific suite of economic and ecological commodities (e.g., hunting and grazing, reeds, rice, or birds).

As new and competing interests enter the marsh ecosystem, introducing novel technologies of hydraulic development, changes in the ecosystem engender a period of instability, crisis, and conflict. Each change in social-ecological relations, particularly the power to name, control, produce, or monopolize resources, pushes the system toward regime destabilization.

The resulting new interventions, typically on the part of state actors, focus on re-engineering the landscape to lessen conflict and adjudicate competing demands. This further re-engineering of the waterworks benefits either different or more diverse interests and leads to the definition or production of newly constituted resources such as reeds, fish, ducks, or herons.

The repetition of such cycles, compounded over one another, cause frictions with the material and ideological legacies of past cycles. These frictions further compel political innovations that lead to temporary stabilization, contestation, or re-adjustment. Thus, current landscape and ecological dynamics embody, and are constituted by, past conflicts and resolutions (Neumann 1998, 2001, Mathevet 2004, Vandergeest and Peluso 2006a,b).

\section{LESSONS FROM THE POLITICAL ECOLOGY OF A DYNAMIC HYDRAULIC REGIME}

The historical political ecology of this wetland reveals five lessons illustrating how historical changes and long-term unresolved conflicts can affect understandings of shifting marsh ecologies and politics. First, evoking Hollander's (2005) findings in a U.S. wetland, the Everglades, we found that political ecology can illuminate analyses of how national conservation actors' constructions of a place as "natural" affect its use, conservation, and management. In this case, we showed how national-level desires and demands in France since the 16th century have caused change and conflict among resource users in the Camargue. By situating contemporary conflicts in historical trajectories of changing uses, ecology, and claims, we have shown how HPE analysis can potentially aid policy formation, if there is actually a willingness among national actors to accept historical data on claims and use and to adapt to or integrate local claims and resource uses.

Second, HPE is a means of identifying historical socio-natures. The appearance of two previously unknown ponds on the 19th century maps was a critical finding: they documented and helped explain subsequent ecological change. The ponds emerged after the reingenering process of the 1800 s and demonstrated that the reed bed degradation started earlier than the 1990s. This finding showed that hunters and reed harvesters were not the only ones responsible for 21 st century degradation.

Third, conservationists used to view the Scamandre Marshes' reed bed environmental decline ahistorically. They blamed marsh resource users for their lack of coordination in water management and/or the inappropriate use of tractors to harvest reeds, without attending to the historical development of multiple, concurrent marsh use rights and the complex connections of current uses to changes imposed by national and international impositions and the long-term ecological effects of earlier changes.
Environmentalist reports and analyses of the 1990s extrapolated from short-term, recent studies of breeding populations of purple herons and Eurasian bitterns, and attributed their declining numbers to what they saw as improper local management, largely blaming hunters and reed harvesters. Oddly, their declentionist narratives contradicted the documented fact that the marsh harbored the Camargue's largest breeding population of purple herons and Eurasian bitterns. The crisis narrative was used to enforce conservation contracts, conservation zoning, and centralized water management by the Department of the Gard. Couched in the terms of ecological science, the story served the interests of particular stakeholders: a few commercial reed cutters, the new management body, and the bird conservation interests. This raises the question of how to use time and history most effectively in planning for resilient landscapes. The process of developing the last management plan for the Scamandre Marshes (in 2001) looked back only 30 years and examined only a limited territory, the Scamandre Marshes' perimeter. These limited spatial and temporal views placed past and larger scale social and ecological dynamics in a black box, missing important events and gradual changes such as the reduction of the reed bed and the creation of two large ponds. Scientists and local authorities thus underestimated the magnitude of the issues and the extent of processes in play because of constraints imposed by previous policy choices and actions. This reflects the "excessive presentism" denounced by the French historian François Hartog (2003) and raises questions about how to understand environmental problems in wetlands.

Fourth, the first three cycles we described show that the destabilization of the marshland water flow regime and the marsh's marginalization occurred following the intervention of an outside authority for the sake of a national-level interest. These affected the Scamandre Marshes by changing outlets downstream and access to fresh water. These latter two effects were generally key parts of each cycle's unresolved contradictions that nourished subsequent social tensions. The changes created and contended with new demands on the marsh from inside and outside the region. Thus, the Scamandre Marshes suffered collateral damage from the realization of a variety of larger regional, national, and international political-economic interests, including the territorial unification of the Kingdom of France, the development of vineyards in the highlands by governing and emergent capitalist elites, and rice farming by nationally sponsored migrants in the peripheral marshes, all of which changed priorities for the allocation of freshwater. In the same way, recent tensions and demands are products of previous cycles, political economic and environmental changes, and conflicts. Many of the conflicts between hunters, reed harvesters, fishers, and livestock breeders arose not from chronic shortages of water or their own mismanagement, but from the political impositions on the marsh environment made by state and private decision makers. The national state's decision to develop rice farming in cycle 3 had a major negative effect on access to water for other marsh stakeholders in cycle 4 . The political domination of the upstream agricultural industry, also created and backed by the national state, limited all other marsh users' access to water during spring and summer. In addition, one environmental indicator of the ongoing social-environmental production of marsh ecology was the discovery that two of the three large ponds present today are of recent origin, not older features as scientists initially thought. 
The fifth lesson comes from the evidence provided of the value of HPE for biodiversity conservation science and practice. No landscape is produced locally or ahistorically. The engineered management of water and land in the Camargue, and people's ongoing dependence and demands on marsh resources, re-made the site's "natural" hydraulic features and demonstrated the difficulty of solely prioritizing the ecological functions of a wetland. In sum, we have stressed here that history is not only a hallmark of political ecology, but a way of understanding ecological changes that can help advance conservation science and policy. Conservation scientists are gaining political influence with the rise of global environmental concerns, yet many remain inattentive to histories of the environment and its uses and related claims. It is not unusual for political ecologists to recommend using social-environmental histories to understand today's environmental problems. However, as we have shown here, it is important to learn to see contemporary environments as manifestations of past socioecological forces that created and constrained the struggles of the present.

${ }^{[1]}$ Deal between the Abbot of Psalmody and the inhabitants of Saint-Laurent, 24 August 1384. Archives of the Department of the Gard. G. 46.

[2] "The tolerance of the construction of dams and levees within the wetlands to retain the waters (...) through the greed of improving the fish harvest by retaining the water. (...) the judgment of the 25th of April 1761 orders the total destruction of dams and levees and generally all waterworks that obstruct the water flow within the marsh." From Vauvert Municipal Archives (VMA), C75 for Monsieur de Joubert by the Syndic du diocèse de Nîmes.

[3] "Even the reeds, this rich production of the marsh so necessary to the subsistence of cattle, perished with the high elevation of the water." From VMA, C75, Saturday 14th of March 1767.

[4] “(...) How many regrets we should have today! When glancing around places so fertile in the past, we caught sight only of stagnant water, releasing during summer [Thermidor] a pestilential smell, causing fatal diseases every year in our lands." VMA, Registre X-38, 18 Pluviose.

[5] For example, in 1875, the communal marshes had a maintenance cost of 2859 French francs for an annual income of 23,235 French francs. VMA, Register X-264, 13 November 1875.

${ }^{[6]}$ The St Gilles commune is accused by the Vauvert commune of pouring its drainage waters in the pond. VMA, Register X-337, 10 April 1895.

[7] "The lots of Grey Marsh numbered 2, 3, 5, 6, 7, and 8 did not produce the income they should have for the commune due to the lack of waterworks.” VMA, Register 10-122, 10 July 1897.

[8] "Fishing is forbidden (...) to favor the stocking of fish in the Scamandre, Crey and Charnier ponds (...)."VMA, Register X-25, 13 June 1913.

${ }^{[9]}$ For instance, "[Fishermen] you ruined the wetland by opening breaches in the dikes of the canal, which let salt water come in (...); comparing our marshes to what they were in the past, these publically owned lands were an inexhaustible source of wealth for the commune, the fodder they produced were more than sufficient to feed our cattle. (...) today what do they offer, a huge water body without any other products than those of fishing." VMA, Register X-25, 31 January 1801.

Responses to this article can be read online at: http://www.ecologyandsociety.org/issues/responses. $\mathrm{php} / 7787$

\begin{abstract}
Acknowledgments:
We thank all stakeholders, professional and nonprofessional historians, and archives staff for participating in or commenting on this study. The work took place in the CAMADAPT project and was conducted with financial support from the French Ministry of Ecology (LITEAU program) and the SETER Project supported by the Agropolis Fondation.
\end{abstract}

\section{LITERATURE CITED}

Bakker, K., and G. Bridge. 2006. Material worlds? Resource geographies and the 'matter of nature'. Progress in Human Geography 30(1):5-27. http://dx.doi.org/10.1191/0309132506ph588oa

Barbraud, C., M. Lepley, R. Mathevet, and A. Mauchamp. 2002. Reedbed selection and colony size of breeding purple herons Ardea purpurea in southern France. Ibis 144(2):227-235. http://dx. doi.org/10.1046/j.1474-919X.2002.00047.X

Barbraud, C., and R. Mathevet. 2000 Is commercial reed harvesting compatible with breeding purple herons Ardea purpurea in the Camargue, southern France? Environmental Conservation 27(4):334-340. http://dx.doi.org/10.1017/ $\underline{\mathrm{S} 0376892900000382}$

Berkes, F., and C. Folke, editors. 1998. Linking social and ecological systems: management practices and social mechanisms for building resilience. Cambridge University Press, Cambridge, UK.

Biehler, D. D. 2009. Permeable homes: a historical political ecology of insects and pesticides in US public housing. Geoforum 40(6):1014-1023. http://dx.doi.org/10.1016/j.geoforum.2009.08.004

Blaikie, P. 1985. The political economy of soil erosion in developing countries. Longman, London, UK.

Blaikie, P., and H. Brookfield, editors. 1987. Land degradation and society. Methuen, London, UK.

Boutonnet, G. 1963. Histoire du dessèchement des marais du BasLanguedoc. Bas-Rhône Languedoc 17:10-26.

Bouvier, M. 1825. Mémoire sur le projet d'amélioration des Marais Inferieurs des Concessionnaires du canal de Beaucaire et de ceux appartenant à la commune de Vauvert. Compagnie des canaux de Beaucaire et d'Aigues-Mortes, Nîmes, France.

Braudel, F. 1985. La dynamique du capitalism. Arthaud, Paris, France.

Braun, B., and N. Castree, editors. 1998. Remaking reality: nature at the millennium. Routledge, London, UK. 
Brockington, D. 2002. Fortress conservation: the preservation of Mkomazi Game Reserve, Tanzania. Indiana University Press, Bloomington, Indiana, USA.

Bryant, R. L. 1997. The political ecology of forestry in Burma, 1824-1994. University of Hawaii Press, Honolulu, Hawaii, USA.

Cabot, J. 1991 Anciens ports et moulins de petite Camargue: aspects d'une civilisation de l'eau. Presse du Languedoc, Montpellier, France.

Cabot, J. 1994. De Posquières à Vauvert du XIII au XVIIe siècle. Mémoires de l'Académie de Nîmes, Series VIII, Volume LXXXI. Académie de Nîmes, Nîmes, France.

Carney, J. A. 2001. Black rice: the African origins of rice cultivation in the Americas. Harvard University Press, Cambridge, Massachusetts, USA.

Carney, J. A., and R. N. Rosomoff. 2009. In the shadow of slavery: Africa's botanical legacy in the Atlantic world. University of Californa Press, Berkeley, California, USA.

Comte de Dienne, L. E. 1891. Histoire du dessèchement des lacs et marais en France avant 1789. H. Champion, Paris, France.

Crumley, C. L. 1994. Historical ecology: cultural knowledge and changing landscapes. School of American Research Press, Santa Fe, New Mexico, USA.

Crumley, C. L., and W. H. Marquardt, editors. 1987. Regional dynamics: Burgundian landscapes in historical perspective. Academic Press, San Diego, California, USA.

Davis, D. K. 2007. Resurrecting the granary of Rome: environmental history and French colonial expansion in North Africa. Ohio University Press, Athens, Ohio, USA.

Davis, D. K. 2009. Historical political ecology: on the importance of looking back to move forward. Geoforum 40(3):285-286. http:// dx.doi.org/10.1016/j.geoforum.2009.01.001

Deleuze, G. 1988. Foucault. Translated and edited by Seán Hand. University of Minnesota Press, Minneapolis, Minnesota, USA.

Fairhead, J., and M. Leach. 1995. False forest history, complicit social analysis: rethinking some West African environmental narratives. World Development 23(6):1023-1035. http://dx.doi. org/10.1016/0305-750x(95)00026-9

Foucault, M. 2004. Sécurité, territoire, population: cours au Collège de France (1977-78). Gallimard/Seuil, Paris, France.

Guigou, É. 1978. Une cité au pays d'oc, de Posquières à Vauvert. Anthropos, Paris, France.

Gunderson, L. H., and C. S. Holling, editors. 2002. Panarchy: understanding transformations in human and natural systems. Island Press, Washington, D.C., USA.

Haraway, D. 1988. Situated knowledges: the science question in feminism and the privilege of partial perspective. Feminist Studies 14(3):575-599. http://dx.doi.org/10.2307/3178066

Hartog, F. 2003. Régimes d'historicité. Présentisme et expériences du temps. Seuil, Paris, France.

Hawke, C. J., and P. V. José. 1996. Reedbed management for commercial and wildlife interests. Royal Society for the Protection of Birds, London, UK.
Hecht, S. B. 2013. The scramble for the Amazon and the "lost paradise" of Euclides da Cunha. University of Chicago Press, Chicago, Illinois, USA. http://dx.doi.org/10.7208/ chicago/9780226322834.001.0001

Hecht, S. B., and A. Cockburn. 1989. The fate of the forest: developers, destroyers, and defenders of the Amazon. University of Chicago Press, Chicago, Illinois, USA.

Hoben, A. 1995. Paradigms and politics: the cultural construction of environmental policy in Ethiopia. World Development 23 (6):1007-1021. http://dx.doi.org/10.1016/0305-750x(95)00019-9

Hollander, G. 2005. The material and symbolic role of the Everglades in U.S. national politics. Political Geography 24 (4):449-475. http://dx.doi.org/10.1016/j.polgeo.2005.01.002

Holling, C. S., L. H. Gunderson, and D. Ludwig. 2002. In quest of a theory of adaptive change. Pages 3-24 in L. H. Gunderson and C. S. Holling, editors. Panarchy: understanding transformations in human and natural systems. Island Press, Washington, D.C., USA.

Honegger, A., B. Caron, and M. Engler. 1992. Eau et environnement en Petite Camargue gardoise, bilan et propositions pour la protection et la gestion du patrimoine naturel. Espace rural 28. Laboratoire de Géographie rurale de l'Université Paul Valéry, Montpellier, France.

Kosek, J. 2005. Understories: the political life of forests in northern New Mexico. Duke University Press, Raleigh, North Carolina, USA. http://dx.doi.org/10.1215/9780822388302

LeFebvre, H. 1991. The production of space. Translated by Donald Nicholson-Smith. Blackwell, Oxford, UK.

Lentheric, C. 1880. La région du bas Rhône, le pays du sel et le canal de Beaucaire à la mer 1880. Revue des Deux Mondes 37 (2):864-891.

Mathevet, R. 2004. Camargue incertaine: sciences, usages et natures. Buchet Chastel, Paris, France.

Mathevet, R., A. Mauchamp, R. Lifran, B. Poulin, and G. Lefebvre. 2003. ReedSim: simulating ecological and economical dynamics of Mediterranean reedbeds. Pages 1007-1012 in D. Post, editor. Integrative modelling of biophysical, social and economic systems for resource management solution. Modelling and Simulation Society of Australia and New Zealand, Townsville, Australia.

Mathevet, R., and B. Poulin. 2006. De la biologie à la géographie de la conservation. Bulletin de l'Association des Géographes Français 2006(3):341-354.

Mathevet, R., and A. Sandoz. 1999. L'exploitation du roseau et les mesures agri-environnementales dans le delta du Rhône. Revue de l'Economie Méridionale 47:101-122.

Mauchamp, A., S. Blanch, and P. Grillas. 2001. Effects of submergence on the growth of Phragmites australis seedlings. Aquatic Botany 69(2-4):147-164. http://dx.doi.org/10.1016/ $\underline{\mathrm{s} 0304-3770(01) 00135-8}$

Mauchamp, A., and F. Mésleard. 2001. Salt tolerance in Phragmites australis populations from coastal Mediterranean marshes. Aquatic Botany 70(1):39-52. http://dx.doi.org/10.1016/ s0304-3770(00)00140-6 
Moore, J. W. 2010. The end of the road? Agricultural revolutions in the capitalist world-ecology, 1450-2010. Journal of Agrarian Change 10(3):389-413. http://dx.doi.org/10.1111/j.1471-0366.2010.00276. $\underline{x}$

Neumann, R. P. 1998. Imposing wilderness: struggles over livelihood and nature preservation in Africa. University of California Press, Berkeley, California, USA.

Neumann, R. P. 2001. Africa's last "wilderness": reordering space for political and economic control in colonial Tanzania. Africa 71(4):641-665.

Neumann, R. P. 2005. Making political ecology. Hodder Arnold, London, UK.

Offen, K. H. 2004. Historical political ecology: an introduction. Historical Geography 32:19-42. [online] URL: https://ejournals. unm.edu/index.php/historicalgeography/article/view/2952/2431.

Peet, R., and M. Watts. 1996. Liberation ecologies: environment, development, social movements. Routledge, London, UK.

Peluso, N. L. 1992. Rich forests, poor people: resource control and resistance in Java. University of California Press, Berkeley, California, USA.

Peluso, N. L. 2009. Rubber erasures, rubber producing rights: making racialized territories in West Kalimantan, Indonesia. Development and Change 40(1):47-80. http://dx.doi.org/10.1111/ j.1467-7660.2009.01505.x

Peluso, N. L. 2012. What's nature got to do with it? A situated historical perspective on socio-natural commodities. Development and Change 43(1):79-104. http://dx.doi.org/10.1111/

j.1467-7660.2012.01755.x

Picon, B. 1988. L'espace et le temps en Camargue. Actes Sud, Arles, France.

Poulin, B., G. Lefebvre, S. Allard, and R. Mathevet. 2009. Reed harvest and summer drawdown enhance bittern habitat in the Camargue. Biological Conservation 142(3):689-695. http://dx.doi. org/10.1016/j.biocon.2008.11.020

Poulin, B., R. Mathevet, and G. Lefebvre. 2006. Integrating bird ecology with socio-economy for a sustainable wetland management. Journal of Ornithology 147(S1):80.

Raffles, H. 2001. In Amazonia: a natural history. Princeton University Press, Princeton, New Jersey, USA.

Robbins, P. 2012. Political ecology: a critical introduction. Second edition. Wiley, Chichester, UK.

Swyngedouw, E. 1999. Modernity and hybridity: nature, regeneracionismo and the production of the Spanish waterscape, 1890-1930. Annals of the Association of American Geographers 89(3):443-465. http://dx.doi.org/10.1111/0004-5608.00157

Teulade, A. 1992. L'éternelle passion palustre posquierovauverdoise. DEA Histoire. Université Paul Valéry, Montpellier, France.

Teulade, A. 1999. La palus et le canal de Capette. Bulletin de la Société d'Histoire de Vauvert-Posquières 5:3-31.
Vandergeest, P., and N. L. Peluso. 2006a. Empires of forestry: professional forestry and state power in Southeast Asia, part 1. Environment and History 12(1):31-64. http://dx.doi. org/10.3197/096734006776026809

Vandergeest, P., and N. L. Peluso. 2006b. Empires of forestry: professional forestry and state power in Southeast Asia, part 2. Environment and History 12(4):359-393. http://dx.doi. org/10.3197/096734006776026809

Vassas, R., and J. Vigneron. 1980. L'aménagement hydro-agricole de la petite Camargue et l'assainissement des marais de la Souteyranne. Bulletin de la Société Languedocienne de Géographie 14:267-296.

Vidal, J. J. 1980. Les résistances à l'assèchement des marais du Bas Languedoc au XVIIIe siècle. Bulletin de la Société Languedocienne de Géographie 14:187-198.

Wallerstein, I. 1974. The modern world system: capitalist agriculture and the origins of the European world economy in the sixteenth century. Academic Press, New York, New York, USA.

Watts, M. 1983. Silent violence: food, famine and peasantry in northern Nigeria. University of California Press, Berkeley, California, USA.

Widgren, M. 2010. Besieged palaeonegritics or innovative farmers: historical political ecology of intensive and terraced agriculture in West Africa and Sudan. African Studies 69 (2):323-343. http://dx.doi.org/10.1080/00020184.2010.499204

Zimmerer, K. S., and T. J. Bassett, editors. 2003. Political ecology: an integrative approach to geography and environment-development studies. Guilford Press, New York, New York, USA. 